\title{
Physiological Response of Vicia faba to Prohexadione-Calcium UNDER SALINe Conditions ${ }^{1}$
}

\author{
Resposta Fisiológica de Vicia faba a Prohexadiona-Cálcio sob Condições Salinas
}

BEKHETA, M.A. ${ }^{2}$, ABDELHAMID, M.T. ${ }^{2}$ and EL-MORSI, A.A. ${ }^{3}$

\begin{abstract}
Changes in the activities of oxidative enzymes (indole acetic acid oxidase, peroxidase and catalase), endogenous hormones (gibberellic acid (GA3), indole acetic acid (IAA), abscisic acid (ABA) and cytokinins (AsZeatin), photosynthetic pigments (chlorophyll $a$, chlorophyll $b$ and carotenoids), total carbohydrates, total soluble sugars, amino acid proline and vegetative growth parameters were used as indicators to explain the physiological role of the growth retardant prohexadione-calcium on Vicia faba seedlings 40 days after sowing under salinity stress for 30 days. The obtained results show that soaking faba bean seeds prior to sowing at different concentrations of prohexadione-calcium $(0,10,20$ and $30 \mathrm{ppm})$ significantly increased the activities of indole acetic acid oxidase (IAA-oxidase) and peroxidase enzymes, but decreased the catalase enzyme activity as compared with their respective control. Application of prohexadione-Ca caused markedly decreases in the endogenous contents of gibberellins and indole acetic acid (IAA) but increased the levels of natural growth inhibitor abscisic acid (ABA) and cytokinins in the shoots of faba bean seedlings. All the prohexadione$\mathrm{Ca}$ concentrations increased the contents of amino acid proline, photosynthetic pigments (chlorophyll $a$, chlorophyll $b$ and carotenoids), total carbohydrates and total soluble sugars in faba bean seedlings grown under salt stress. Application of prohexadione-Ca decreased significantly seedling height and shoot fresh weight but significantly increased shoot dry weight.
\end{abstract}

Keywords: endogenous hormones, faba bean, growth retardant, oxidative enzymes, salinity.

RESUMO - Mudanças nas atividades de enzimas oxidativas (oxidase, peroxidase e catalase do ácido indol-acético), hormônios endógenos (ácido giberélico (GA3), ácido indol-acético (AIA), ácido abscísico $(A B A)$ e citocininas (AsZeatin)), pigmentos fotossintéticos (clorofila a, clorofila b e carotenóides), carboidratos totais, açúcares solúveis totais, aminoácido prolina e parâmetros de crescimento vegetativo foram usados como indicadores para explicar a função fisiológica do retardante de crescimento prohexadiona-cálcio em plântulas de Vicia faba aos 40 dias após a semeadura cultivadas sob estresse salino por 30 dias. Os resultados obtidos mostram que a embebição das sementes de fava antes da semeadura em diferentes concentrações de prohexadiona-cálcio $(0,10,20$ e 30 ppm) aumentou significativamente as atividades de ácido indol-acético oxidase (AIA-oxidase) e enzimas peroxidase, porém diminuiu a atividade da enzima catalase quando comparada com seu respectivo controle. A aplicação de prohexadiona-Ca causou decréscimos marcantes nos teores endógenos de giberelinas e ácido indol-acético (AIA), mas aumentou os niveis do inibidor de crescimento natural ácido abscísico (ABA) e citocininas nas partes aéreas das plântulas de fava. Todas as concentrações de prohexadionaCa usadas aumentaram os teores do aminoácido prolina, dos pigmentos fotossintéticos (clorofila a, clorofila b e carotenóides), dos carboidratos totais e dos açúcares solúveis totais em plântulas de fava cultivadas sob estresse salino. A aplicação de prohexadiona-Ca diminuiu significativamente a altura das plântulas e o peso fresco de parte aérea mas aumentou significativamente o peso seco da parte aérea.

Palavras-chave: hormônios endógenos, feijão fava, retardante de crescimento, enzimas oxidativas, salinidade.

Recebido para publicação em 20.3.2009 e na forma revisada em 13.11.2009.

2 Associate Professor of Plant Physiology, Botany Department, National Research Centre, Al-Behoos street, Dokki 12622, Cairo, Egypt, <mbekheta@yahoo.com>, <magdi.abdelhamid@yahoo.com>; ${ }^{3}$ Emeritus Professor of Plant Physiology and Ex-head of Botany Department, National Research Centre, Al-Behoos street, Dokki 12622, Cairo, Egypt.

Planta Daninha, Viçosa-MG, v. 27, n. 4, p. 769-779, 2009 


\section{INTRODUCTION}

Salinity is considered as a severe problem in agriculture since it results in a noticeable reduction in crop productivity. Lack of fresh water for irrigation, together with poor drainage of water from the cultivated soils, resulted in the accumulation of salts. In Egypt, the cultivated regions restricted to the Nile Valley, which depends on fresh water of the Nile River for irrigation, does not exceed $4 \%$ of the total Egypt land area. Most of the newly reclaimed lands depend on underground water of various degrees of salinity for irrigation. In addition, progressive accumulation of salts became a serious problem in many cultivated areas of the Delta as a result of high ground watertable, especially when accompanied by poor drainage.

Faba bean (Vicia faba) is considered the main leguminous crop grown in Egypt as its seeds are used for human consumption. Thus, many efforts have been consistly made to increase its productivity. As fresh water resources and the area allotted for this crop are not sufficient to meet the food demand of the increasing population (about 80 million) in Egypt, cultivation of marginal area together with the use of hard water may solve this problem.

Salinity stress in nature is mainly due to excess of sodium salts; particularly sodium chloride $(\mathrm{NaCl})$. There is general agreement that salinity stress at certain critical stages in plant growth causes more injuries arising from high accumulation of salts (Ashraf, 2004; Abdelhamid et al., 2009). In spite of the advanced technology and management, about $50 \%$ of the irrigated land in the world is affected by secondary salinization or sodicity and water logging (Szaboles, 1976).

Over the last two decades application of growth retardants for manipulation of growth and development of numerous plant species and varieties for intensive plant production has increased rapidly in many research institutions (Cerny-Konig et al., 2005).

Many investigators reported that growth regulators in general and growth retardants in particular are effective tools in increasing salt tolerance of plants (Younis et al., 1994; Muthukumarasamy \& Penneerselvam, 1997; Bekheta, 2000; Bekheta et al., 2006).
One of the comparatively new growth retardants is prohexadione-calcium (Phd-ca) compound of antigibberellin in nature, (i.e., it reduces longitudinal shoot growth by inhibiting gibberellin biosynthesis by blocking the $3, \beta$ hydroxylation of $\mathrm{GA}_{20}$ to $\mathrm{GA}_{1}$ ). It is translocated basipetally as well as acropetally and plays an important role in overcoming various environmental stresses (Nakayama et al., 1992). Recently, Asin et al. (2007) reported that application of prohexadione-Ca increased growth and yield of pear orchard plants growing under biotic and abiotic stresses conditions.

Thus, the present investigation was undertaken in a trail to alleviate the harmful effects of salinity on bean seedlings by using a new growth regulator prohexadione- $\mathrm{Ca}$ (phdca). It aimed to increase the salt tolerance of faba bean seedlings using prohexadione-ca, through its effects on many physiological processes.

\section{MATERIAL AND METHODS}

Pot experiments were carried out during two successive growth seasons $(2005 / 2006$ and 2006/2007) under greenhouse conditions at the National Research Centre, Dokki, Cairo, Egypt (29.77 N, $31.3 \mathrm{E}$ ), for 40 days from 29 November 2005 to 8 January 2006 and from 26 November 2006 to 5 January 2007. Day temperature ranged from 6 to $21^{\circ} \mathrm{C}$ with an average of $16.7 \pm 3.5^{\circ} \mathrm{C}$. right temperature was $7.6 \pm 3.2^{\circ} \mathrm{C}$, with minimum and maximum of 1 and $16{ }^{\circ} \mathrm{C}$, respectively. Daily relative humidity averaged $52.8 \pm 4.8 \%$, in a range between 26.9 and $63.0 \%$.

Faba bean (Vicia faba) seeds were obtained from the Agricultural Research Center, Ministry of Agriculture and Land Reclamation, Egypt. The seeds were selected for uniformity by choosing those of equal size and same color. The selected seeds were washed with distilled water, sterilized with $1 \%$ sodium hypochlorite solution for about $2 \mathrm{~min}$. and thoroughly washed again with distilled water. The seeds were soaked for $12 \mathrm{~h}$ at required concentrations of the growth retardant prohexadione-calcium, removed from the solutions, left to dry at room temperature $\left(25^{\circ} \mathrm{C}\right)$ for about $1 \mathrm{~h}$. Five uniform air dried faba bean seeds were sown along a 
centre row in each pot at $30 \mathrm{~mm}$ depth in $15 \mathrm{~cm}$ diameter plastic pots, each filled with about $5 \mathrm{~kg}$ soil from Giza, consisting of the upper $0.1 \mathrm{~m}$ of soil collected from an area of undisturbed native vegetation at 4 plant growth retardant levels x $\mathrm{NaCl}$ salinity x 1 harvest. The factorial experiment laid out in a randomized block design with nine replicates. At sowing, a granular commercial rhizobia was incorporated into the top $30 \mathrm{~mm}$ of the soil in each pot with the seeds. Ten days after sowing, the seedlings were thinned to two seedlings per pot.

The soil had a clay texture $(20 \%$ sand, $20 \%$ silt and $60 \%$ clay) with pH 8.52 in $0.01 \mathrm{M}$ $\mathrm{CaCl}_{2}$; $\mathrm{EC} 0.70 ; \mathrm{OM} 1.36 ; \mathrm{CaCO}_{3} 1.43 ; \mathrm{P} 6.46 \mathrm{mg}$

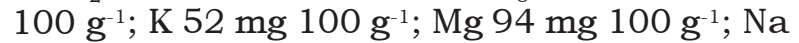
$13 \mathrm{mg} 100 \mathrm{~g} \mathrm{~g}^{-1}$; Ca $150 \mathrm{mg} 100 \mathrm{~g}^{-1}$; Fe 9.2 PPM, Mn 9.3 PPM; Zn 3.9 PPM; Cu 2.5 PPM. In order to reduce compaction and improve drainage, the soil was mixed with yellow sand in a 4:1 proportion. Granular ammonium sulphate $20.5 \% \mathrm{~N}$ at a rate of $40 \mathrm{~kg} \mathrm{~N} \mathrm{ha}^{-1}$, and single superphosphate $\left(15 \% \mathrm{P}_{2} \mathrm{O}_{5}\right)$ at a rate of $54 \mathrm{~kg}$ $\mathrm{P}_{2} \mathrm{O}_{5}$ ha $^{-1}$ were added to each pot. The $\mathrm{N}$ and $\mathrm{P}$ fertilizers were mixed thoroughly into the soil of each pot immediately before sowing. Soil field capacity in the pots was estimated by saturating the soil in the pots with water and weighing them after they had drained for 48 h. Field water capacity was 0.36 .

The growth regulator used was prohexadione-Ca, a plant growth retardant manufactured by Sigma-Aldrich Laborchemikalien $(\mathrm{GmbH}$ D-30918, Seelze). The substance wettable powder with $82.5 \%$ activity has chemical structure of calcium salt [3, 5 dioxo- 4 propionylcyclohexan-carboxylic acid], with the molecular formula $\mathrm{C}_{10} \mathrm{H}_{10} \mathrm{Ca} \mathrm{O}_{5}$, molecular weight $250.26 \mathrm{~g} \mathrm{Mol}^{-1}$. water solubility $96.6 \%$ at $20^{\circ} \mathrm{C}$. The concentrations of prohexadione-Ca used in this study, namely, 0, 10, 20 or $30 \mathrm{ppm}$ were calculated on the basis of active ingredient.

Irrigation water consisted of three concentrations of salt (tap water, 2000 and $3000 \mathrm{ppm}$ ) in the form of sodium chloride $(\mathrm{NaCl})$, applied 10 days after sowing (DAS) and maintained for 30 days. The tap water had 150 ppm salt.

Soil water content was checked by weighing and daily loss of water supplemented twice (morning and afternoon) with one of the previous $\mathrm{NaCl}$ solutions. Soil water content was maintained at about $65 \%$ of field water capacity.

Faba bean seedlings were harvested at 40 days after sowing (DAS) and divided as follows:

Group A: 36 pots were used to measure shoot height $(\mathrm{cm})$, shoot fresh weight and dry weight after drying in an electrical oven at $60^{\circ} \mathrm{C}$ for $72 \mathrm{~h}$, grounded and stored for chemical analysis.

Group B: 36 pots were used to obtain the plant shoots which were immediately weighed, frozen with liquid nitrogen and stored in a deep freezer at $-20^{\circ} \mathrm{C}$ until extraction and estimation of some endogenous hormones.

Group C: 36 pots were used for estimation of photosynthetic pigments, oxidative enzymes (IAA oxidase, peroxidase \& catalase) and proline content in new leaves.

An accurate weight (0.5 g) of fresh young leaves of Vicia faba seedlings were homogenized in $85 \%$ acetone and used for estimation of photosynthetic pigments the (chlorophyll $a$, chlorophyll $b$ and total carotenoids), using the spectrophotometric method developed by Gilley \& Fletcher (1998).

Total carbohydrates were determined in the shoots of faba bean seedlings using the colorimetric method described by Herbert et al. (1971). The method used for extraction and determination of total soluble sugars was similar to that described by Pucher et al. (1957). Amino acid free proline was determined in the fresh young leaves of Vicia faba seedlings according to the colorimetric method described by Bates et al. (1973).

The oxidative enzymes (indole acetic acid oxidase (IAA-oxidase), peroxidase and catalase) were extracted from the new leaves of faba bean seedlings according to the methods described by Kar \& Mishra (1976). The activity of IAA-oxidase enzyme was carried out according to the method of Darbyshire (1971) and modified by Mittal \& Dubey (1992). Peroxidase enzyme was assayed following the method of Kar \& Mishra (1976) with slight modifications according to El-Telwany (1987). The activity of catalase enzyme was carried 
out according to the method described by Mittal \& Dubey (1992).

Extraction and chemical estimation of endogenous hormones were carried out by high performance liquid chromatography (HPLC) as follows:

The frozen plant material (shoot seedlings) was homogenized with ice-cold absolute methanol in a blender and stored at $3{ }^{\circ} \mathrm{C}$ for about $24 \mathrm{hr}$. The alcohol was filtered and two subsequent extractions were made with $80 \%$ ice-cold methanol. The combined alcoholic extracts were evaporated to the aqueous phase at a temperature not exceeding $30^{\circ} \mathrm{C}$ under reduced pressure (Badr et al., 1971). The aqueous phase was adjusted to $\mathrm{pH} 8.2$ with $1 \mathrm{~N} \mathrm{KOH}$ and portioned three times against equal volumes of petroleum ether to remove the lipids, pigments and other undesirable substances. The petroleum ether phase was discarded. Separation of gibberellins and auxins was carried out according to Hiraja et al. (1972). The acidic aqueous phase was adjusted to $\mathrm{pH} 7.0$ with $1 \mathrm{~N} \mathrm{KOH}$ and partitioned 4 times against equal volumes of $n$-butanol saturated with water ( $5 \mathrm{~min}$ each time). The butanol layer was collected and evaporated to dryness. The extracted samples were dissolved in $100 \mu \mathrm{L}$ of HPLC grade methanol and a volume of $6 \mu \mathrm{L}$ of the solution (equivalent $20 \mathrm{~g}$ fresh weight) was injected into silica column containing Li chrospher Si-60 super (Merck, $4 \mathrm{~mm}$, cartridge $125 \mathrm{x} 4 \mathrm{~mm}$ ) eluted by a linear gradient of solvent system from 20 to $70 \%$ methanol containing $0.05 \%$ acetic acid over from $80-20 \%$ water containing $0.05 \%$ with running time $30 \mathrm{~min}$. In case of detection of cytokinins (as zeatin) eluted isocratically using elution solvents (methanol: ammonium formate 40:60 $\mathrm{Ph} 3.7$ ) over a running time of $8 \mathrm{~min}$. Endogenous hormones, namely gibberellic acid (GA3), indole acetic acid (IAA), abscisic acid (ABA) and cytokinins (as Zeatin) were detected by their absorption at $255 \mathrm{~nm}$ and the peak area of the samples were compared to the corresponding peak areas of standard solutions containing known concentrations.

The data of the two seasons were subjected to statistical analysis of variance and the combined analysis for the two seasons was calculated later (Steel \& Torrie, 1960) since the results showed the same trend. The LSD value was calculated whenever the $F$ values were significant at $5 \%$ level of probability (Snedecor \& Cochran, 1982).

\section{RESULTS AND DISCUSSION}

\section{Seedling growth}

As shown in Table 1, irrigation of faba bean seedlings with saline solutions $(2,000$ and $3,000 \mathrm{ppm}$ ) resulted in significant reduction in shoot height and shoot fresh and dry weights compared with tap water. These findings are in agreement with those obtained in bean seedlings (Phaseolus vulgaris) by Stoeva \& Kaymakanova (2008). Soaking of faba bean seeds in solutions of prohexadione-Ca caused significant reduction in shoot height and shoot fresh weight. The reduction corresponded with increasing prohexadione$\mathrm{Ca}$ concentration. However, shoot dry weight (SDW) was significantly increased with increasing prohexadione-Ca concentration. The interactive effects between $\mathrm{NaCl}$ and prohexadione-Ca were significant where the lowest values of shoot height and fresh weight were $14.9 \mathrm{~cm}$ and $13.6 \mathrm{~g}$ per shoot, while the highest value of shoot DW were $2.8 \mathrm{~g}$ per shoot, found when $\mathrm{NaCl} 3,000$ ppm interacted with GR 30 ppm.

Several reports (Gent, 1997; Bekheta, 2000, 2004; Asin et al., 2007) emphasized our findings. Reduction in most vegetative growth parameters caused by the combined treatments could be due to the reduction in the cell size which might be attributed to changes in osmotic cell enlargement dependent on solute accumulation, i.e., due to drastic changes in ion relationship (Grossmann et al., 2006).

\section{Photosynthetic pigments}

Stress in general, and salinity in particular, result in the occurrence of physiological disorders in crop plans. Table 2 shows that irrigation of faba bean seedlings with saline solutions (2000 and/or 3000 ppm) decreased significantly the photosynthetic pigments of faba bean leaves (chl. $a$, chl. $b \&$ carotenoids) and this reduction increased with increasing $\mathrm{NaCl}$ concentration. These results are in agreement with those obtained by Starck \& Karwowska (1978). They concluded that 
Table 1 - Effect of different concentrations of prohexadione-Ca (phd-Ca) in the soaking solution of faba bean seeds grown under different levels of $\mathrm{NaCl}$ salinity on shoot height, shoot fresh and dry weights at 40 DAS

\begin{tabular}{|c|c|c|c|c|c|c|c|c|c|c|c|c|}
\hline \multirow{3}{*}{\begin{tabular}{|l} 
Treat \\
Phd-Ca \\
\end{tabular}} & \multicolumn{4}{|c|}{ Shoot height $(\mathrm{cm})$} & \multicolumn{4}{|c|}{ Shoot fresh weight (g) } & \multicolumn{4}{|c|}{ Shoot dry weight (g) } \\
\hline & \multicolumn{3}{|c|}{ Salinity levels } & \multirow{2}{*}{ Mean } & \multicolumn{3}{|c|}{ Salinity levels } & \multirow{2}{*}{ Mean } & \multicolumn{3}{|c|}{ Salinity levels } & \multirow{2}{*}{ Mean } \\
\hline & $150 \mathrm{ppm}$ & $2,000 \mathrm{ppm}$ & $3,000 \mathrm{ppm}$ & & $150 \mathrm{ppm}$ & $2,000 \mathrm{ppm}$ & $3,000 \mathrm{ppm}$ & & $150 \mathrm{ppm}$ & $2,000 \mathrm{ppm}$ & $3,000 \mathrm{ppm}$ & \\
\hline $0.0 \mathrm{ppm}$ & 25.5 & 23.0 & 20.0 & 22.8 & 23.8 & 22.1 & 17.5 & 21.1 & 2.1 & 2.0 & 1.9 & 2.0 \\
\hline $10 \mathrm{ppm}$ & 22.2 & 19.0 & 17.9 & 19.7 & 23.0 & 18.1 & 17.1 & 19.4 & 2.6 & 2.4 & 2.2 & 2.4 \\
\hline $20 \mathrm{ppm}$ & 18.5 & 17.0 & 16.0 & 17.2 & 21.5 & 16.7 & 15.1 & 17.7 & 2.8 & 2.6 & 2.7 & 2.7 \\
\hline $30 \mathrm{ppm}$ & 15.7 & 15.0 & 14.9 & 15.2 & 20.7 & 14.8 & 13.6 & 16.4 & 3.0 & 2.8 & 2.8 & 2.9 \\
\hline Mean & 20.5 & 18.5 & 17.2 & & 22.3 & 17.6 & 15.8 & & 2.6 & 2.5 & 2.4 & \\
\hline \multirow{2}{*}{ LSD $0.5 \%$} & \multicolumn{3}{|c|}{$\mathrm{S}=1.99 \mathrm{GR}=1.2$} & & \multicolumn{3}{|c|}{$\mathrm{S}=2.89 \mathrm{GR}=2.28$} & & \multicolumn{3}{|c|}{$\mathrm{S}=0.13 \mathrm{GR}=0.24$} & \\
\hline & \multicolumn{3}{|c|}{$\mathrm{S} \times \mathrm{GR}=2.2$} & & \multicolumn{3}{|c|}{$\mathrm{S} \times \mathrm{GR}=3.15$} & & \multicolumn{3}{|c|}{$\mathrm{S} \times \mathrm{GR}=\mathrm{NS}$} & \\
\hline
\end{tabular}

$\mathrm{S}=$ salinity; GR $=$ Growth retardant; $\mathrm{S} \times \mathrm{GR}=$ Interaction between salinity and growth retardant.

Table 2 - Effect of different concentrations of prohexadione-Ca (phd-Ca) in soaking solution of faba bean seeds grown under different levels of $\mathrm{NaCl}$ salinity on photosynthetic pigments of leaves at $40 \mathrm{DAS}$

\begin{tabular}{|c|c|c|c|c|c|c|c|c|c|c|c|c|}
\hline \multirow{3}{*}{$\begin{array}{l}\text { Treat } \\
\text { Phd-Ca }\end{array}$} & \multicolumn{4}{|c|}{$\begin{array}{c}\text { Chlorophyll } a \\
\text { (mg g }{ }^{-1} \text { fresh weight) }\end{array}$} & \multicolumn{4}{|c|}{$\begin{array}{c}\text { Chlorophyll } b \\
\text { (mg g }{ }^{-1} \text { fresh weight) }\end{array}$} & \multicolumn{4}{|c|}{$\begin{array}{c}\text { Carotenoids } \\
\left.\text { (mg g } \mathrm{m}^{-1} \text { fresh weight }\right)\end{array}$} \\
\hline & \multicolumn{3}{|c|}{ Salinity levels } & \multirow{2}{*}{ Mean } & \multicolumn{3}{|c|}{ Salinity levels } & \multirow{2}{*}{ Mean } & \multicolumn{3}{|c|}{ Salinity levels } & \multirow{2}{*}{ Mean } \\
\hline & $150 \mathrm{ppm}$ & $2,000 \mathrm{ppm}$ & $3,000 \mathrm{ppm}$ & & $150 \mathrm{ppm}$ & $2,000 \mathrm{ppm}$ & $3,000 \mathrm{ppm}$ & & $150 \mathrm{ppm}$ & $2,000 \mathrm{ppm}$ & $3,000 \mathrm{ppm}$ & \\
\hline $0.0 \mathrm{ppm}$ & 3.1 & 2.8 & 2.2 & 2.7 & 1.3 & 1.1 & 1.0 & 1.1 & 0.70 & 0.55 & 0.50 & 0.58 \\
\hline $10 \mathrm{ppm}$ & 3.5 & 3.0 & 2.9 & 3.1 & 1.5 & 1.4 & 1.3 & 1.4 & 1.00 & 0.86 & 0.71 & 0.86 \\
\hline $20 \mathrm{ppm}$ & 4.0 & 3.7 & 3.2 & 3.6 & 1.6 & 1.5 & 1.4 & 1.5 & 1.20 & 1.00 & 0.85 & 1.00 \\
\hline $30 \mathrm{ppm}$ & 4.2 & 3.9 & 3.7 & 3.9 & 1.8 & 1.6 & 1.5 & 1.6 & 1.50 & 1.30 & 0.90 & 1.23 \\
\hline Mean & 3.7 & 3.3 & 3.0 & & 1.6 & 1.4 & 1.3 & & 1.10 & 0.93 & 0.74 & \\
\hline \multirow{2}{*}{ LSD $0.5 \%$} & \multicolumn{3}{|c|}{$\mathrm{S}=0.23 \mathrm{GR}=0.27$} & & \multicolumn{3}{|c|}{$\mathrm{S}=0.15 \mathrm{GR}=0.18$} & & \multicolumn{3}{|c|}{$\mathrm{S}=0.1 \mathrm{GR}=0.14$} & \\
\hline & \multicolumn{3}{|c|}{$\mathrm{S} \times \mathrm{GR}=0.51$} & & \multicolumn{3}{|c|}{$\mathrm{S} \times \mathrm{GR}=0.29$} & & \multicolumn{3}{|c|}{$\mathrm{S} \times \mathrm{GR}=0.23$} & \\
\hline
\end{tabular}

$\mathrm{S}=$ salinity; GR $=$ Growth retardant; $\mathrm{S} \times \mathrm{GR}=$ Interaction between salinity and growth retardant.

inhibition of photosynthetic pigments of bean leaves irrigated with $\mathrm{NaCl}$ may be attributed to the inhibition of assimilate translocation. Bhivare et al. (1988) reported that salinity stress markedly affected the rate of photosynthetic carbon assimilation of bean leaves. Reddy $\&$ Vora (1983) attributed the reduction in photosynthetic pigments of wheat leaves grown under salt stress to increase in the activity of chlorophyllase enzyme. Recently, Stoeva \& Kaymakanova (2008) reported that treating bean seedlings (Phaseolus vulgaris) different concentrations of saline solutions resulted in reduction of the photosynthetic pigments.

Soaking of faba bean seeds at different concentrations of prohexadione-Ca caused significant increases in the photosynthetic pigment content of faba bean leaves, compared with those obtained from untreated seedlings. These results are in agreement with those obtained by Fletcher \& Hofestra (1985) who reported that using growth retardant resulted in several modifications to plants, such as increase in chlorophyll levels and enlarged chloroplasts. Bekheta et al. (2006) reported that using the growth retardant uniconazole resulted in several modifications in faba bean plants, such as increase in chlorophyll levels and enlarged chloroplasts.

The interactive effects between $\mathrm{NaCl}$ and prohexadione-Ca were significant where the highest values of chl. $a$, chl. $b \&$ carotenoids 
were $4.2,1.8 \& 1.5$, respectively, when GR $30 \mathrm{ppm}$ interacted with tap water. That means that GR $30 \mathrm{ppm}$ increased significantly the photosynthetic pigments compared to all other GR concentrations over all salinity levels. These results are in agreement with those obtained by Panneerselvam et al. (1997) and Bekheta et al. (2006).

\section{Total carbohydrates and total soluble sugars}

Table 3 shows that salinity level of 2,000 and 3,000 ppm caused significant decrease in total carbohydrate content of faba bean shoots, compared with tap water. This trend might be a result of reduction in photosynthetic activity and/or respiration in order to provide enough energy for water and nutrient absorption (Nieman, 1965). Ebad et al. (1990) reported that reduction in the total carbohydrates of sunflower and maize plants, grown under higher levels of salinity, may be attributed to increase in amylase activity.

Salinity at 2,000 and 3,000 ppm increased the total soluble sugars of faba bean shoots (Table 3). Prohexadione-Ca with all concentrations increased significantly total carbohydrates and total soluble sugars, compared to control. This increase was correlated positively with increasing its concentration. The increases in the amounts of these criteria as a result of prohexadioneCa treatments might be attributed to the increase of photosynthetic pigments thus increasing the photosynthesis rate. These results are in agreement with those obtained by Srivastava et al. (1988) and Abo-Elkheir (1993), who observed that increase in total soluble sugars content as a result of salinization might be attributed to osmotic adjustment (as osmoregulation) of wheat and trail to maintain its turgidity and overcome the increased resistance to water uptake in roots.

The interaction effect of salinity combined with prohexadiione-Ca was significant in both traits total carbohydrates and total soluble sugars. The highest values were obtained with higher concentrations of $\mathrm{NaCl}$ salinity and prohexadione-Ca. The results obtained in this investigation are in agreement with those obtained by several investigators (Kim et al., 1994; Farahat \& E1-Liethy, 1995; Bekheta 2000, 2004). In addition, Grossmann et al. (2006) demonstrated that increases in total soluble sugars content of prohexadione-Ca treated plants may be attributed to the decrease in the activity of amylase enzyme.

\section{Proline content}

Proline is believed to protect plant tissue against stress by acting as a nitrogen-storage compound, osmo-solute and hydrophobic protectant for enzymes and cellular structures (Greenway \& Munus, 1980).

Table 3 - Effect of soaking faba bean seeds at different concentrations of prohexadione-Ca (phd-Ca) on total carbohydrate, total soluble sugars and amino acid proline of faba bean leaves grown under different levels of $\mathrm{NaCl}$ salinity at 40 DAS

\begin{tabular}{|c|c|c|c|c|c|c|c|c|c|c|c|c|}
\hline \multirow{3}{*}{$\begin{array}{l}\text { Treat } \\
\text { Phd-Ca }\end{array}$} & \multicolumn{4}{|c|}{$\begin{array}{l}\text { Total carbohydrates } \\
\text { (mg g }{ }^{-1} \text { dry weight) }\end{array}$} & \multicolumn{4}{|c|}{$\begin{array}{l}\text { Total soluble sugars } \\
\text { (mg g } \mathrm{m}^{-1} \text { dry weight) }\end{array}$} & \multicolumn{4}{|c|}{$\begin{array}{l}\text { Amino acid praline } \\
\text { ( mole } \mathrm{g}^{-1} \text { fresh weight) }\end{array}$} \\
\hline & \multicolumn{3}{|c|}{ Salinity levels } & \multirow{2}{*}{ Mean } & \multicolumn{3}{|c|}{ Salinity levels } & \multirow{2}{*}{ Mean } & \multicolumn{3}{|c|}{ Salinity levels } & \multirow{2}{*}{ Mean } \\
\hline & $150 \mathrm{ppm}$ & $2,000 \mathrm{ppm}$ & $3,000 \mathrm{ppm}$ & & $150 \mathrm{ppm}$ & $2,000 \mathrm{ppm}$ & $3,000 \mathrm{ppm}$ & & $150 \mathrm{ppm}$ & $2,000 \mathrm{ppm}$ & $3,000 \mathrm{ppm}$ & \\
\hline $0.0 \mathrm{ppm}$ & 69.0 & 67.8 & 58.0 & 64.9 & 17.0 & 19.6 & 20.0 & 18.9 & 13.9 & 14.6 & 15.6 & 14.7 \\
\hline $10 \mathrm{ppm}$ & 70.5 & 72.5 & 65.9 & 69.6 & 20.9 & 21.0 & 22.2 & 21.4 & 16.0 & 16.1 & 16.7 & 16.3 \\
\hline $20 \mathrm{ppm}$ & 75.8 & 74.5 & 70.1 & 73.5 & 21.5 & 23.7 & 23.9 & 23.1 & 16.2 & 17.0 & 17.0 & 16.7 \\
\hline $30 \mathrm{ppm}$ & 80.8 & 81.9 & 75.8 & 79.5 & 22.1 & 24.0 & 24.0 & 23.0 & 17.7 & 18.0 & 19.1 & 18.3 \\
\hline Mean & 74.0 & 74.2 & 67.4 & & 20.4 & 22.1 & 22.5 & & 16.0 & 16.4 & 17.1 & \\
\hline \multirow{2}{*}{ LSD $0.5 \%$} & \multicolumn{3}{|c|}{$\mathrm{S}=4.20 \mathrm{GR}=3.11$} & & \multicolumn{3}{|c|}{$\mathrm{S}=2.70 \mathrm{GR}=2.24$} & & \multicolumn{3}{|c|}{$\mathrm{S}=1.80 \mathrm{GR}=1.31$} & \\
\hline & \multicolumn{3}{|c|}{$\mathrm{S} \times \mathrm{GR}=5.65$} & & \multicolumn{3}{|c|}{$\mathrm{S} \times \mathrm{GR}=3.83$} & & \multicolumn{3}{|c|}{$\mathrm{S} \times \mathrm{GR}=3.10$} & \\
\hline
\end{tabular}

$\mathrm{S}=$ salinity; GR $=$ Growth retardant; $\mathrm{S} \times \mathrm{GR}=$ Interaction between salinity and growth retardant. 
Table 3 shows that saline solutions resulted in significant increases in proline content of faba bean leaves and that this increment corresponded to increasing salinity concentration. This finding is in agreement with results of Stoeva \& Kaymakanova (2008), who reported that saline solutions led to increased proline content of bean seedlings.

Significant increases in proline content of faba bean were found to be a result of soaking faba bean seeds with different concentrations of prohexadione-Ca $(10,20$ or $30 \mathrm{ppm}$ ) compared to tap water. The increase was gradual by increasing the prohexadioneCa concentration, with $30 \mathrm{ppm}$ presenting the highest values of proline content. The interactive effect of $\mathrm{NaCl}$ salinity and prohexadione-Ca was significant and highest values of proline were found in faba bean leaves with higher concentrations of $\mathrm{NaCl}$ salinity and prohexadione-Ca. Thus soaking faba bean seeds before sowing at different concentrations of prohexadione-ca may add more protection of the plants to salinity stress. Weimberg et al. (1982) proposed a specific role for proline in osmoregulation and suggested that proline accumulation in the cytoplasm allows maintenance of a balance across the tonoplast. In addition, Esaka \& Hayakawa (1995) and Bekheta et al. (2006) found that application of growth retardants from secretion of proline-rich protein by salt adopted bean cells may be specific to the adaptation of the cell wall to salt stress and may cause changes in the cell wall that allow, allowing cells to tolerate salt stress.

\section{Oxidative enzymes}

\section{Activities of IAA-oxidase and peroxidase}

Figure 1 shows the interactive effects of salinity and prohexadione-Ca on IAA-oxidase and peroxidase enzymes of faba bean leaves. Irrigation of faba bean with different levels of $\mathrm{NaCl}$ salt up to $3000 \mathrm{ppm}$ caused increase in the activity of IAA-oxidase and peroxidase enzymes, compared with control Figure 1. Activities of IAA-oxidase and peroxidase enzymes were increased with increasing prohexadione-Ca concentrations compared with control (Figure 1). Activities of IAAoxidase and peroxidase enzymes increased with increasing salt and prohexadione-Ca concentrations, compared with control. These results are in agreement with those obtained by Darbyshire (1971) and Mall et al. (1981) who found that the activity of IAA-oxidase in rice and pea plants increased under the influence of water stress. Winston (1990) reported that water stress could increase the accumulation of peroxidase substances such as glutathione, ascorbate and phenolic compounds which in turn act as scavengers of cell harmful reactive oxygen species $\left(1 / 2 \mathrm{O}_{2}\right)$. In addition, Bekheta (2000) reported that soaking faba bean seeds at different concentrations of the growth retardant uniconazole ranging from (0.0$40 \mathrm{ppm}$ ) and irrigating the plants with saline solutions up to $4000 \mathrm{ppm}$ increased the activity of IAA-oxidase and peroxidase, compared with their corresponding control.

\section{Catalase activity}

The interactive effects of salinity and prohexadione-Ca on catalase activity of faba bean leaves are shown in Figure 1. Irrigation of faba bean with 2,000 and $3,000 \mathrm{ppm}$ of $\mathrm{NaCl}$ salt significantly reduced the activity of catalase enzyme compared with the control (Figure 1). Catalase activity enzyme decreased with increasing prohexadione-Ca concentrations (Figure 1). Catalase activity decreased with increasing salt and prohexadione-Ca concentrations, compared with control. The results obtained in this work are in agreement with those obtained by Zaki et al. (1995) and Bekheta (2000) who reported that soaking faba bean seeds in different concentrations of uniconazole $(10,20$ or $30 \mathrm{ppm}$ ) and irrigated with different levels of salinity up to $4,000 \mathrm{ppm}$ led to reduction in catalase activity. In other words, the reduction in catalase activity resulted in accumulation of toxic amounts of hydrogen peroxide $\left(\mathrm{H}_{2} \mathrm{O}_{2}\right)$ which might restrict shoot growth, elevated $\left(\mathrm{H}_{2} \mathrm{O}_{2}\right)$ concentrations that could release peroxidase from the cell membrane structure (Gorden \& Beck, 1997; Nguyen et al., 2005).

\section{Endogenous hormones}

Figure 2 shows the interactive effects of salinity and prohexadione-Ca on endogenous hormones, namely gibberellic acid (GA3), 

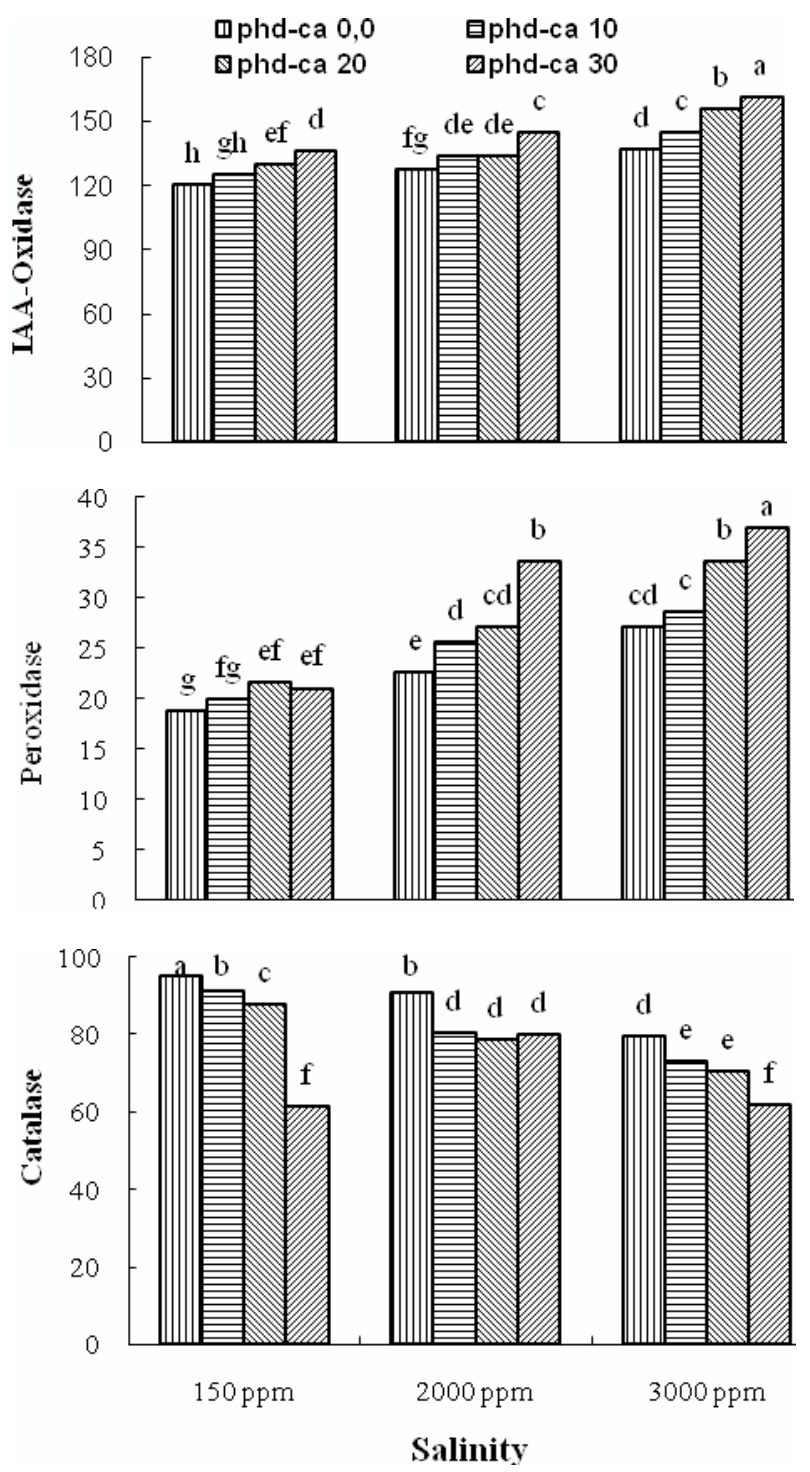

Bars with no common letter are significantly different as determined by $\operatorname{LSD}(\mathrm{p}<0.05)$.

* The unit of activity of IAA-oxidase enzyme was expressed as oxidation of $\mu \mathrm{g}$ of IAA h-1 $\mathrm{g}^{-1}$ fresh weight under the experimental conditions. The activity of peroxidase enzyme was expressed as changes in the optical density at $430 \lambda / \mathrm{g}$ fresh weight/1h. The catalase activity unit was was expressed as oxidation of $1 \mu$ mole of $\mathrm{H}_{2} \mathrm{O}_{2} / \mathrm{min}$ fresh weight, under the experimental conditions.

Figure 1 - Interactive effect of $\mathrm{NaCl}$ salinity and prohexadione$\mathrm{Ca}$ on activities of IAA-oxidase, peroxidase and catalase enzymes of faba bean leaves at 40 DAS.

indole acetic acid (IAA), abscisic acid (ABA) and cytokinins (as Zeatin). Application of salt at all levels significantly reduced the amounts of GA3, IAA and cytokinins, ABA, compared to the control. Decreases and increases were directly proportional to the salt concentrations used.

Application of prohexadione-Ca decreased the levels of GA3 and IAA but increased the levels of ABA and cytokinins in faba bean seedlings, compared with their respective controls (Figure 2). The lowest values of GA3 and IAA were found using $30 \mathrm{ppm}$ of prohexadione-Ca, compared with other prohexadione-Ca concentrations, under each salinity level.

The reduction in the level of GA3 due to application of prohexadione-Ca, as shown in Figure 2 could be due to the interference of the compound with GA3 biosynthesis. This occurs through the inhibition of biosynthetic oxidation of ent-kaurene to ent-kaurenic acid and accumulation of ent-kaurene (Kim et al., 1994). The decrease in the content of IAA caused by prohexadione-Ca treatments could be due to conversion of auxins to an inactive compound by some biochemical processes, e.g., oxidation and/or increase in the activity of IAA- oxidasse enzyme (Wang et al., 1991).

Irrigating faba bean with salt combined with application of prohexadione-Ca significantly increased the content of ABA, compared with control and the increases coincided with the concentration used of salt and prohexadione-Ca (Figure 2). The increase in the content of ABA could be a consequence of an event or more during metabolic sequence, which activates or synthesizes growth inhibitors. Elevated levels of abscisic acid are a typical response to water deficit induced by drought or salinity, suggesting that this plant growth regulator may participate in stress-reduced responses. Such elevated ABA levels in the leaves are important for rapid osmotic adjustment via stomatal closure (Khan et al., 1993). Abscisic acid-induced water stress tolerance are associated with increased net synthesis of some specific protein, whereas proline probably alleviates water stress injury through the direct protection of cellular water stress components (Xin \& Li, 1993). It is interesting to mention that Davies \& Jones (1991) had suggested that ABA synthesis is regulated at the transcriptional level and following an increase in ABA, there is a modification of gene expression in the stressed plants. 

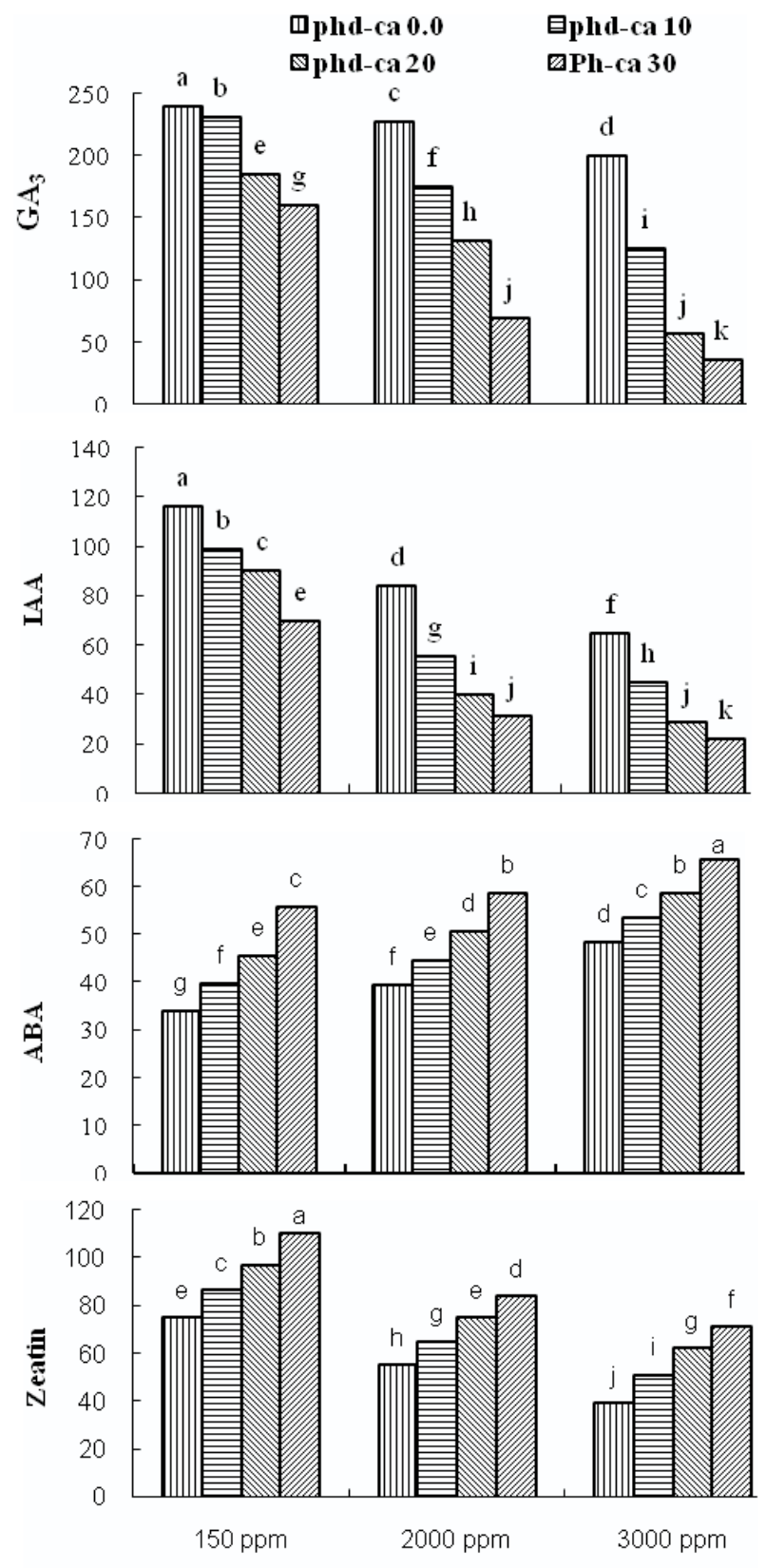

Salinity

Figure 2 - Interactive effect of $\mathrm{NaCl}$ salinity and prohexadione$\mathrm{Ca}$ on the endogenous hormones (ng/g fresh weight) of faba bean shoot at 40 DAS.

In the present study, the reduction in the levels of auxins, gibberellins and cytokinins in faba bean seedlings subjected to salinity stress could be attributed to reduction of their biosynthesis resulting from osmotic stress disturbance and/or their destruction or transformation to inactive bound forms. In this connection, the reduction in the level of IAA recorded in this study was accompanied by increases in the activity of IAA-oxidase and peroxidase enzymes. Similar results were obtained by Nayek et al. (1982). Peroxidase catalyzed degradation of indole-3-acetic acid (IAA) results in the formation of indole-3methanol (IM) in the presence of phenolic compounds or to 3-hydroxymethyloxindole (HMOX) in their absence. Apparently, the phenols compete with a methyleneindolenine intermediate for $\mathrm{H}_{2} \mathrm{O}_{2}$, which is produced by oxidase action preceding peroxidase action in the course of IAA degradation (LangenbeckSchwich \& Grambow, 2006).

The content of cytokinins was significantly increased in faba bean shoot with increasing prohexadione-Ca concentrations while significantly reduced due to salt. Increases or reductions coincided with the concentrations of prohexadione-Ca or salt (Figure 2). Similar results were obtained by Bekheta (2000), who reported that the growth retardant uniconazole increased the levels of cytokinins in the shoots of Vicia faba plants grown under salinity stress.

In conclusion, the growth retardant prohexadione-Ca may counteract the harmful effects of salinity at 2,000 or $3,000 \mathrm{ppm}$ on the growth and development of Vicia faba seedlings. The effect was more pronounced at the concentration of 20 and $30 \mathrm{ppm}$ prohexadione-Ca, used for soaking faba bean seeds prior to sowing.

\section{LITERATURE CITED}

ABDELHAMID, M. T.; SHOKR, M. B.; BEKHETA, M. A. Effects of induced salinity on growth, root characteristics and leaf nutrient accumulation of four faba bean (Vicia faba L.) cultivars differing in their broomrape tolerance. Agric. Res. J., v. 9, n. 1, p. 59-67, 2009 .

ABO-ELKHEIR, M. S. A. Effect of $\mathrm{GA}_{3}$ and Pix on growth and yield of wheat plants grown under different levels of soil moisture. Ann. Agric. Sci., v. 31, n. 4, p. 1777-1782, 1993.

ASHRAF, M. Some important physiological selection criteria for salt tolerance in plants. Flora, v. 199, n. 5, p. 361-376, 2004.

ASIN, L.; ALEGRE, S.; MONTSERRAT, R. Effect of paclobutrazol, prohexadione-ca, deficit irrigation, summer pruning and root pruning on shoot growth, yield and return bloom in "Blanquilla" pear orchard. Sci. Hortic., v. 113, n. 2, p. 135-142, 2007. 
BADR, S. A.; MARTIN, G. C.; HARTMANN, H. T. A modified method for and identification of $\mathrm{ABA}$ and gibberellin like substances from the olive (Olea). Physiol. Plant., v. 24, n. 2, p. 191-198, 1971.

BATES, L. S.; WALDREN, R. P.; TEARE, I. D. Rapid determination of free proline for water-stress studies. Plant Soil, v. 39, n. 1, p. 205-207, 1973.

BEKHETA, M. A. Physiological studies on the effect of uniconazol on the growth and productivity of Vicia faba plants grown under different levels of salinity stress. 2000. 212 f. Thesis (Ph.D.) Faculty of Science, Cairo University, Cairo, 2000

BEKHETA, M. A. A. Combined effect of gibberellic acid and paclobutrazole on wheat plants grown in newly reclaimed lands. J. Agric. Sci., v. 29, n. 8, p. 4499-4512, 2004.

BEKHETA, M. A.; SHABAZ, R.; LIEBEREI, R Uniconazole induced changes of stress responses of Vicia faba L. polyphenol oxidase activation pattern serves as an indicator for membrane stability. J. Appl. Bot Food Qual., v. 80, n. 2 , p. $129-134,2006$

BHIVARE, V.N.; NIMBALKAR, J.D.; CHAVAN, P.D Photosynthetic carbon metabolism in French bean leaves under saline conditions. Environ. Exper. Bot., v. 28, n. 2, p. 117-121, 1988.

CERNY-KONIG, T. A.; FAUST, J. E.; RAJAPAKSE, N. C. Role of gibberellin a (4) and gibberellin biosynthesis inhibitors on flowering and stem elongation in petunia under modified light environments. HortScience, v. 40, n. 1, p. 134-137, 2005

DARBYSHIRE, B. The effect of water stress on indole acetic acid oxidase in pea plants. Plant Physiol., v. 47, n. 1, p. $65-67,1971$.

DAVIES, W. J.; JONES, H. G. Abscisic acid physiology and biochemistry. Oxford, Bios Scientific Publishers, 1991.

EBAD, F. A. et al. Interacting effects of $\mathrm{NaCl}$ and $\mathrm{GA}_{3}$ or $\mathrm{CCC}$ on protease and amylase activity in sunflower and maize. Desert Inst. Egypt., v. 40, n. 1, p. 159-178, 1990.

EL-TELWANY, K. A. E. Effect of soil drought on certain physiological aspects in plants. 1987. $343 \mathrm{f}$. (Thesis Ph.D.) Faculty of Science, Ain Shams University, Cairo, 1987.

ESAKA, M. M.; HAYAKAMA, H. Specific secretion of proline-rich proteins by salt-adapted winged bean cells. Plant and Cell Phisiology, v. 36, n. 3, p. 441-446, 1995.

FARAHAT, M. M.; EL-LEITHY, A. S. Response of Chrysanthemum cinerafolium Vis plant to some growth retardants. Egyptian J. Appl. Sci., v. 10, n. 11, p. 36-51, 1995.
FLETCHER, R. A.; HOFSTRA, G. Triadimefon a plant multi-protectant. Plant Cell Phisiol., v. 26, n. 4, p. 775-780, 1985.

GENT, M. P. N. Persistence of triazole growth retardants on stem elongation of rhododendron and kalmia. J. Plant

Growth Regul., v. 16, n. 4, p. 197-203, 1997.

GILLEY,A.; FLECHER, R. A. Gibberellin antagonizes paclobutrazole induced stress protection in wheat seedlings. J. Plant Physiol., v. 103, n. 1-2, p. 200-207, 1998.

GRODEN, D.; BECK, E. $\mathrm{H}_{2} \mathrm{O}_{2}$ destruction by ascorbate dependent systems from chloroplasts. Biochem. Biophys. Acta, v. 546, n. 3, p. 426-435, 1997.

GREENWAY, H.; MUNNS, R. Mechanism of salt tolerance of non halophytes. Ann. Rev. Plant Physiol., v. 31, n. 1, p. 149-190, 1980.

GROSSMANN, K.; KONIG-KARNZ, S.; KWIATKOWSKI, J. Phytohormonal changes in intact shoots of wheat and oilseed rape treated with the acylcyclohexanedione. Physiol. Plant., v. 90, n. 1, p. 139-143, 2006.

HERBERT, D.; PHILIPS, P.; STRANGE, R. Determination of total carbohydrates. Method Microbial, v. 58, p. 209-344, 1971.

HIRAJA, K. et al. Isolation and characterization of free gibberellins and glycosyl-esters of gibberellins in mature seeds of Phaseolus vulgaris. Agric. Biol. Chem., v. 36, n. 2, p. 345-347, 1972.

KAR, M.; MISHRA, D. Catalase, peroxidase and polyphenloxidase activities during rice leaf senescence. Plant Physiol., v. 57, n. 2, p. 315-319, 1976.

KHAN, T. L. et al. Characterization of expression of drought and Abscisic acid regulated tomato genes in the droughtresistant species Lycopersicon pennellii. Plant Physiol., v. 103 , n. 2 , p. $597-605,1993$.

KIM, H. Y.; CHOI, J. B.; SANG, K.C. Effects of uniconazole on drought resistance of Pilea cardieri. II. Physiological changes and drought resistance. J. Korean Soc. Hortic. Sci., v. 35 , p. $493-498,1994$.

LANGENBECK-SCHWICH, B.; GRAMBOW, H. G. Metabolism of indole-3-acetic acid and indole-3-methanol in wheat leaf segments. Physiol. Plant., v. 61, n. 1, p. 125-129, 2006.

MALL, P. C. et al. Changes in the activity of some enzymes and free proline in rice during water stress. Plant Biochem. J., v. 7, n. 2, p. 126-133, 1981 
MITTAL R.; DUBEY, S. R. Influence of $\mathrm{NaCl}$ salinity on polyphenol oxidase, IAA-Oxidase and catalase activities in rice seedlings differing in salt tolerance. Tropical Sci., v. 35, n. 2, p. 141-149, 1995.

MUTHUKUMARASAMY, M; PANNEERSELVAM, R. Amelioration of $\mathrm{NaCl}$ stress by triadimefon in peanut seedlings. Plant Growth Regul., v. 22, n. 3, p. 157-162, 1997.

NAKAYAMA, I. et al. Effect of plant growth regulator prohexadione-calcium (BX 112) on the endogenous levels of gibberellins in rice. Plant Cell Physiol., v. 33, n. 1, p. 59-62, 1992.

NAYEK, B.; BISWAS, A. K.; CHOUDHARI, M. A. Water stress - induced changes in enzymatic activities with age and development of field grown rice. Phyton. Rev. Inter. Bot. Exper., v. 42, p. 103-110, 1982.

NIEMAN, R. H. Expansion of bean leaves and its suspension by salinity. Plant Physiol., v. 40, n. 1, p. 156-161, 1965.

NGUYEN,H. T. et al. Effects of salt stress on ion accumulation and antioxidative enzymes activities of Oryza sativa L. and Echincola oryzicola vasing. Weed Biol. Manag., v. 5, n. 1, p. 1-7, 2005.

PANNEERSELVAM, R.; MUTHUKUMARASAMY, M.; KARIKALAN, L. Triadimefon enhances growth and net phofosynthetic rate in $\mathrm{NaCl}$ stressed plants of Raphanus sativus L. Photosynthetica, v. 34, n. 4, p. 605-609, 1997.

PUCHER, W. G. et al. Methods in enzymology. New York: Academic Press, 1957. v. 3

REDDY, M. P.; VORA, A. B. Effect of salinity on germination and free proline contente of bajra (Pennisetum typhoides S \& H) seedlings. Proc. Indian. Nat. Sci. Acad., B49, p. 702-705, 1983.

SNEDECOR, G. M.; COCHRAN, W. G. Statistical methods 7.ed. Ames: The Iowa State University Press, 1980. 507 p.

SRIVASTAVA, T. P. et al. Effect of salt stress on physiological and biochemical parameters of wheat. Ann. Arid Zone, v. 27, n. 3, p. 197-204, 1988
STARCK, Z:; KARWOWSKA, R. Effect of salt stress on the hormonal relation of growth, photosynthesis and distribution of $\mathrm{C}_{14}$ assimilate in bean plants. Acta Soc. Bot. Pol., v. 47, p. $245-267,1978$.

STEEL, R.G. D.; TORRIE, J. H. Principles and procedures of statistics. New York: McGraw-Hill, 1990. 107 p.

STOEVA, N.; KAYMAKANOVA, M. Effect of salt stress on the growth, photosynthetic rate of bean plants (Phaseolus vulgaris L.). J. Central Europ. Agric., v. 9, n. 3, p. 385-392, 2008.

SZABOLES, I. Present and potential salt effected soils prognosis of salinity and alkalinity. Soil Bull., v. 31, p. 9-11, 1976.

WANG, S. Y; JAO, H. J.; FAUST, M. Changes in the activities of catalase, peroxidase and polyphenol oxidase in apple buds during bud break induced by Thidiazuran. J. Plant Growth Regul., v. 18, n. 1-4, p. 33-39, 1991.

WEIMBERG, R.; LERNER, H. R.; POLJAKOF, A. A Relationship between potassium and proline accumulation in salt stressed sorghum bicolor. Physiol. Plant., v. 55, n. 1, p. 5-10, 1982 .

WINSTON, G. W. Physiochemical basis for free radical formation in cells: Production and defense in stress responses. In: ALSCHE, R. G.; CUMMING, J. R. (Eds.). Plants adaptation and acclimation mechanisms. New York: Wiley-Liss, 1990. p. 57-86.

XIN, Z.; LI, P. H. Relationship between proline and Abscisic acid in the induction of chilling tolerance in maize suspension cultured cells. Plant Physiol., v. 103, n. 2, p. 607-613, 1993.

YOUNIS, M. E.; ABAS, A. M.; SUKRY, M. W. Salinity and hormone interaction in affecting growth transpiration and ionic relations (Phaseolus vulgaris L.). Biologia Plant., v. 36, n. 1, p. 83-89, 1994.

ZAKY, L. M.; ABD EL HAMID, M.; EL MASHAD, A. A. Some physiological effects of Abscisic acid on Vicia Faba plants II- Changes in the endogenous auxins, growth inhibitors and certain oxidative enzymes. Egypt. J. Physil. Sci., v. 19, n. 1-2, p. 143-156, 1995. 